\title{
Evaluating The Effect of Integrated Use of Farm Yard Manure and Urea on the Socio economic Performance of Tomato (Lycopersiconesculentum Mill) at Tselemti Woreda, North western Tigray, Ethiopia
}

\author{
Gebremedhn Gebretsadkan
}

Tigray Agricultural Research Institute(TARI), Shire-Maitsebri Agricultural Research Center, Shire, Ethiopia.

\begin{abstract}
As compared to the potential productivity \& national average yield of the crop, farmers in Tselemti 'woreda are not getting as much tomato yield /profit as expected, because of the low soil fertility \& un proper soil management practices. To mitigate the problem farmers commonly use a blanket recommendation of inorganic fertilizers. But currently most farmers are not applying inorganic fertilizers at recommended rates,because of the high price of inorganic fertilizers. Hence, use of FYM would be un avoidable, particularly for resource poor farmers. However FYM alone may not be enough to meet the nutrient requirements of high yielding tomato varieties. So, integrated use of organic and inorganic plant nutrient sources help to overcome problems with the sole application and have moreeconomic profit. This study was therefore conducted with the objective of evaluating the economic feasibility of combined use of FYM \& Urea nutrient sources in tomato production \& assessing farmer's perception on the use \& advantage for sustainable \&better tomato production, in Tselemtiwereda, May ani site during the 2012/13 off season time. Organic (FYM) and inorganic (Urea) nutrient sources was integrated in different proportions to supply $60 \mathrm{Kgha}^{-1}$ of Nitrogen $(N)$ from both sources at different ratios. The treatment combinations are T1 (control or with no fertilizer), T2 (100\%IF), T3 (25\% FYM+75\%IF), T4 (50\% FYM+50IF), T5 (75\%FYM+25\%IF) \& T6 (100\%FYM).Three 'kebeles' and 72 farmers was surveyed for the perception data.The partial budget analysis revealed that maximum net of return (59902.45) Birr/ha was recorded in treatments that receive $25 \% N$ from $F Y M$ in conjunction with $75 \% N$ from $I F$ sources followed by 50\%N from FYM and 50\%IF with a net return of 56,386birrha $a^{-1}$ and $23,862.45$ and 15,896.5 net
\end{abstract}

return over the control. The Perception of the respondent farmers also indicates that $94.4 \%$ of the answered farmers use inorganic fertilizers in tomato production, but $48.61 \%$ of them were responded use of inorganic fertilizer in tomato production is not economically feasible and $44.4 \%$ use an integration of both nutrient sources for better tomato productivity. The overall study revealed that a combined application of FYM with Urea at (25:75 and 50:50 ratios) significantly increased economic profit in tomato production. Therefore, it is recommended for tomato producers of Tselemti wereda for profitable \& acceptable tomato production.

Keywords-FYM, Inorganic, Integrated, Organic, Net return, Tomato, Urea.

\section{INTRODUCTION}

In terms of profitability, evidence of positive returns is often found for integrated mineral organic system (Sedaf and Qasimkhan, 2010). The integration of FYM and inorganic fertilizer on maize in Zimbabwe resulted in a return to the labor of about $\$ 1.35$ per day, while the best single fertilizer or manure treatment yielded only $\$ 0.25$ (Mekuria and Waddington, 2002). The profitability of alternative nutrient input sources depends not only on yield gains but also on market conditions (Place et al., 2003).

Through the conventional understanding the best way to improve the productivity of resource poor farmers is the use of high-yielding variety of crops and chemical fertilizer; however research evidences show that the resulting yield increases may not be sufficient to pay for these inputs (Christopher, 1994). The addition of any amount of fertilizer is interesting to farmers if and only if it is profitable through 
the enhancement of either yield or quality. Mostly, maximum profits are rare at maximum yields because the last increment of fertilizer to produce a little more yield may cost more than the yield increase is worth. Any new technology can be evaluated in terms of its impact on the productivity, profitability, acceptability and sustainability of farming systems. Integrated nutrient management practices are survival and risk avoidance strategies for farmers. Many farmers understand the role of FYM in improving soil quality and sustaining yield (Duncan et al., 1990).

Tolesaa and Friesen (2001) reported that the application of 25\% recommended inorganic NP fertilizers mixed with FYM resulted in the highest marginal rate of return in maize indicating that the integrated approach can enable to save up to $75 \%$ of commercial fertilizers. Likewise, Bayuet al. (2006) also reported the possibility of saving up to $50 \%$ of the recommended NP fertilizers due to amendment with 5-15 t ha $^{-1}$ FYM to sorghum crop without significantly affecting the optimum possible yield that can be obtained with the application of full dose of inorganic NP fertilizers alone.

Farmers' decisions to adopt a new technology in preference to other alternative technologies depend on complex factors (Tesfaye, 2003). One of the factors is the farmers' perception to the characteristics of the new technology. The typical characteristics of a technology are relative advantage, complexity, compatibility, risk and uncertainty. While farmers do not necessarily make conscious and sophisticated analysis of the degree of risk in adopting technology, they are aware of the implication of particular choices. If a farmer's actual experience with the innovation is satisfactory, his/her perceptions probably will become more favorable (Van den Ban and Hawkins, 1998).

Farmers' opinions towards the use of either organic or inorganic sources of plant nutrients are influenced by a variety of factors such as: information sources, ethical concerns about the environment, farmers' knowledge, economic considerations (cost and benefit aspects), marketing procedures, the rationale of the extension system and the like (Chouichom and Yamao, 2010). Many researchers reviewed lots of reasons that farmers are frustrated in using mineral fertilizer such as: the ever increasing price ofmineral fertilizer is becoming beyond the purchasing power of farmersand fear of burning effect by chemical fertilizers on crops when moisture is limiting (Hailu, 2010). Generally, the frustration of the smallholder farmers is to escape possible crisis when the prices of their farm products are too low or lost in the unpredictable rainfall situation. Therefore, farmers are inclined into locally available resources and technologies such as the use of FYM, Butit is not possible to obtain a higher crop yield(profit) by using organic manure alone due to their unavailability in excess amount and they contain a comparatively low quantity of nutrients compared to inorganic fertilizers.

However, no study has been done on the use of integrated fertilization on the economic profit \& social perception of irrigated tomato so far in the study area.Therefore, the aim of this research was to study the impact of combined use of FYM and urea nutrient sources on the economic profitability \& social aspects of irrigated tomato on Tselemtiworeda, Northern Ethiopia.

\section{MAREIALS AND METHODS}

The field experiment was conducted at North Western Zone of Tigray, TselemtiworedaMay ani 'kebele' on farmer fields during the off season of 2012/2013.

From the total 21 village 'kebeles' of the 'woreda' three kebeles (May ani, Medhanialem and Whdet) were selected purposively (Purposive Sampling) for the survey data, based on their accessibility, good potential and better experience in irrigated tomato production using Probability Proportional to Sample size (PPS) method.The target population was those farmers which have at least five years' experience in the production of irrigated tomato. A total of 544 farmers was selected from the three 'kebeles' that fulfill the criteria with the assistance of the extension staffs of each 'kebele', To make it have a sense of statistic, using the PPS method, 72 households were selected from these 544 households.

Table.1: Method of sample size determination of the respondents using PPS

\begin{tabular}{llll}
\hline S/N & Kebele name & No Total HHs selected & Using PPS \\
\hline $\mathbf{1}$ & Whdet & 280 & 37 \\
$\mathbf{2}$ & Medhanialem & 150 & 20 \\
$\mathbf{3}$ & Mai ani & 114 & 15 \\
\hline
\end{tabular}

Source: Tselemtiwereda office of agriculture and rural development(2005);PPS=Probablity proportional to size

Descriptive survey design for data collection was adopted in the study. Primary data were collected from the respondents with the aid of a structured interview consisting of both open and close ended questions. The secondary data were 
also gathered from various sources including Tselemti office of agriculture and rural development, and Maitsebri Agricultural Research Center (MyARC).Besides, relevant literature, official reports were also consulted as a secondary data source. Primary data were collected from sampled farmers who had involved at least for five years in tomato production. Pre-tested interview schedule and checklists were employed as survey instruments.

Based on the 2007 national census conducted by the Central Statistical Agency (CSA, 2007) of Ethiopia, the 'woreda' has a total population of 138,858 of whom 70,108 are men and 68,750 women.A total of 30,485 households resulting in an average of 4.55 persons per household. Various land use types i.e rain fed cultivated land, irrigated land, grazing land, forest land, home stead and the like are existing.The 'woreda' has a total area of 70926ha with 30,365 ha arable land,7000ha irrigated land, 4577ha forest land, 14882 ha grazing and bush land and 14102ha gully and mountainous land (MyARC, 2010).

For economic evaluation of the cost and benefit in using the different ratios of organic and inorganic fertilizers, the Partial Budget Analysis (PBA), which includes the Dominance Analysis (DA) and Marginal Rate of Return (MRR), was used following the CYMMYT procedure (CIMMYT, 1998). In this study, the partial budget analysis was made to determine the most economically acceptable treatments (combinations) by estimating the costs and benefits based on the current market price of tomato fruit, inorganic fertilizers and the spreading costs of farmyard manure for the cropping season at the study area.

The varying labor costs were estimated based on the existing rate of payment to daily farm laborers. The fruit yield harvested from the experimental plots was converted into hectare bases. Then, the market value of the fruit yields was based on the prevailed market price. To estimate economic parameters, tomato was valued at an average open market price of 200.00 birr per quintal $(100 \mathrm{~kg})$ of fruit. The price of 20 work days (WD) per hectare for collection and application of FYM (Astewel, 2010) at a wage rate of 50 Birr per workdays was used. Since the local market for the applied TSP as a source of phosphorus was not available the cost was calculated by changing to DAP equivalent. So, the price of inorganic fertilizers at the time of transplanting in the area was 1500.00 Birr per quintal for DAP and 1250.00 Birr per quintal for Urea. Experimental yields are often higher than the yields that farmers could expect using the same treatments; hence in economic calculation yields of farmers are adjusted by $15 \%$ less than that of the research results (CIMMYT, 1998). Based on this principle the yield obtained from each treatment was changed to hectare basis and reduced by $15 \%$ for economic analysis and the analysis was undergone through the following stages:

Net Income: Estimate the net benefit arising from all alternative treatments. Net income (NI) is calculated as the amount of money left when the total variable costs of inputs (TVC) are deducted from the total revenue (TR).

Dominance Analysis: Before proceeding with the calculation of Marginal Rates of Return, an initial examination of the costs and benefits of each treatment, called dominance analysis is important. Dominance analysis is used to eliminate some of the treatments from further consideration in the MRR and thereby simplifying the analysis of MRR. i.e., those treatments which involve higher cost but do not generate higher benefits (called dominated treatments) are eliminated. The dominance analysis was carried out by first listing all the treatments in their order of increasing costs that vary (TVC) and their net benefits (NB) are then put aside. Any treatment that has higher TVC but net benefits that are less than or equal to the preceding treatment (with lower TVC but higher net benefits) is dominated treatment (marked as" $\mathrm{D}$ "). The dominance analysis illustrates that to improve farmers' income, it is important to pay attention to net benefits rather than yields, because higher yields do not necessarily mean higher net benefits.

The Marginal Rate of Return: is used to assess relative profitability among alternative treatments. It measures the percentage increase in net income in relation with each additional input of expenditure ( $\triangle \mathrm{TVC}$ ) and the $100 \%$ rate of return was considered as a minimum value, which farmers could be willing to invest given their level of poverty and the fragile nature of the environment (CIMMYT, 1998). MRR was calculated as the ratio of change in return on the average of each replicated treatment to the change in total cost with regard to the control. It compares the increments in costs and benefits between pairs of treatments.

$\operatorname{MRR}=\Delta \mathrm{NI} \quad \mathrm{X} 100$

$\Delta \mathrm{TVC}$

Where:

$\Delta \mathrm{NI}=$ Change in Net Income;

$\Delta \mathrm{TVC}=$ change in Total Variable Cost 
The marginal rates of return appear in between two treatments. It makes no sense to speak of the marginal rate of return of a particular treatment because the MRR is a characteristic of the change from one treatment to another.

Identification of a candidate recommendation from among the non-dominated treatments: This is the treatment which gives the highest net return and a marginal rate of return greater than the minimum considered acceptable to farmers.

The social data collected were analyzed with the aid of the descriptive statistical tools of frequency count and percentage.

Simple descriptive statistics such as simple measures of mean, standard deviation, frequency, percentages and cross tabulation were used for the survey data gathered from the sampled farm households. Statistical package for social science (SPSS) version 16 was employed to analyze the data.

\section{RESULTS AND DISCUSSION}

Effect of Integrated use of Organic and IF on Economic Performance

The economic analysis revealed, how gross returns and net benefits were influenced by the integrated use of organic and inorganic plant nutrient sources on irrigated tomato productivity(Table 2). Based on the current market price of economic yield (output) and prevailing price of inputs during the production period, maximum net of return of Birr $59902.45 \mathrm{ha}^{-1}$ was recordedin the plots that receive $25 \% \mathrm{~N}$ from FYM (4.5t/ha) in conjunction with $75 \% \mathrm{~N}$ from inorganic $(97.5 \mathrm{Kg} / \mathrm{ha}$ Urea) sources

Followed by $50 \%$ FYM combined with $50 \%$ of urea with an average net benefit of birr 56386birrha ${ }^{-1}$. It was noted that the integrated use of organic manure with mineral fertilizer at 25:75 and 50:50 ratios were economically profitable and resulted in high net return. However the lowest net return (36040 Birr/ha) was received in the control treatment (Table 2). Similar results were reported by Alamet al., (2004)who observed that higher profit was obtained when inorganic fertilizer was combined with organic manures.

Table.2: TVC cost and NR of tomato as influenced by the integrated use of fertilizers

\begin{tabular}{|c|c|c|c|c|c|c|}
\hline \multirow[t]{2}{*}{ Trts } & \multicolumn{2}{|c|}{ Combinations } & \multirow{2}{*}{$\begin{array}{l}\text { Gross return } \\
\left(\text { birr } \mathbf{h a}^{-1}\right)\end{array}$} & \multirow[t]{2}{*}{ TVC } & \multirow{2}{*}{$\begin{array}{l}\text { Net return } \\
\left(\text { birrha }^{-1}\right)\end{array}$} & \multirow{2}{*}{$\begin{array}{l}\text { Net return over } \\
\text { control }\end{array}$} \\
\hline & $\begin{array}{l}\text { FYM } \\
\left(\text { tha }^{-1}\right)\end{array}$ & $\begin{array}{l}\text { IF(Urea) } \\
\left(\text { kgha }^{-1}\right)\end{array}$ & & & & \\
\hline T1 & 0 & 0 & 36040 & 0 & 36040 & - \\
\hline $\mathbf{T} 2$ & 0 & 130 & 55624 & 3687.5 & 51936.5 & 15896.5 \\
\hline T3 & 4.5 & 97.5 & 63818 & 3915.55 & 59902.45 & 23862.45 \\
\hline $\mathbf{T 4}$ & 9 & 65 & 60061 & 3675 & 56386 & 20346 \\
\hline T5 & 13.5 & 32.5 & 52411 & 4137.5 & 48273.5 & 12233.5 \\
\hline T6 & 18 & 0 & 47515 & 4600 & 42915 & 6875 \\
\hline
\end{tabular}

FYM=Farm Yard Manure; IF=Inorganic fertilizer; TVC=Total Variable Cost

From the agronomic point of view, the best results were obtained from plots which received combined nitrogen (organic and inorganic) i.e. $25 \% \mathrm{~N}$ from FYM with $75 \% \mathrm{~N}$ from inorganic fertilizers, yielded better than the rest of treatment combinations.(Table 3). lists the total costs that vary and the net benefits for each of the treatments in the integrated use of organic (FYM) and inorganic (Urea) plant nutrients for tomato production. This used to identify the inferior treatments i.e. those which involve higher costs but do not generate higher benefits (dominated treatment). To proceed through the dominance analysis, treatments were listed in order of increasing total costs that vary and their corresponding benefits were put aside. This illustrates that to improve farmers' income it is important to pay attention to net benefits, rather than yields. As indicated in (Table 3), $\mathrm{T}_{1}$ showed theleast TVC $(0)$ while $\mathrm{T}_{6}$ showed the maximum TVC (6400 Birr) and all the remaining treatments were confined between these two ranges. As goes from treatment $\left(\mathrm{T}_{1}\right)$ to treatment $\left(\mathrm{T}_{4}\right)$ both the TVC and net profit increases, but for treatment $\left(T_{2}\right)$ the total variable cost is increased but showed lower net benefits than treatment $\left(\mathrm{T}_{4}\right)$ (56386). No farmer would choose $T_{2}$ in comparison with $T_{4}$, because $\mathrm{T}_{2}$ has higher costs that vary, but lower net benefits. Such a treatment is called a dominated treatment (marked with a "D" (Table 3).On the other hand as goes from treatment $\mathrm{T}_{2}$ to treatment $\mathrm{T}_{3}$ both the TVC and the net benefit are increased and considered for further analysis of MRR. The 
rest treatments $\left(\mathrm{T}_{5}\right.$ and $\left.\mathrm{T}_{6}\right)$ are dominated were not considered for further analysis.

Therefore, from the total six treatments only three treatments $\left(T_{1}, T_{3}\right.$ and $\left.T_{4}\right)$ were considered for analysis of Marginal rate of return (MRR) (Table 3). Marginal Rates of Return (MRR) appear in between two treatments. It makes no sense to speak of the marginal rate of return of a particular treatment; rather, the marginal rate of return is a characteristic of the change fromone treatment to another. Since dominated treatments were not included in the marginal analysis, the marginal rate of return was positive. The marginal rate of return indicates what farmers can expect to gain, on the average, in return for their investment when they decide to change from one practice (or set of practices) to another. From the present day experiment combined use of FYM and inorganic fertilizers at the rate of $25 \% \mathrm{~N}$ from FYM with $75 \% \mathrm{~N}$ from inorganic and $50 \%$ from FY M with $50 \%$ from inorganic could be considered to have an economic advantage over the use of other alternative combinations. So to improve farmers' income decision cannot be taken regarding these treatments without knowing what rate of return is acceptable to the farmers rather attention should be given to the net benefits because higher yield does not necessarily mean high net benefit

Table.3: Economic analysis for integrated use of fertilizers in tomato

\begin{tabular}{lllllllll}
\hline Trts & \multicolumn{2}{l}{ Combinations } & $\begin{array}{l}\text { Yield } \\
\left(\text { Qlha }^{-1}\right)\end{array}$ & $\begin{array}{l}\text { GR } \\
\left(\text { (birr ha- }^{-1}\right)\end{array}$ & TVC & $\begin{array}{l}\text { NR } \\
\left(\text { birrha }^{-1}\right)\end{array}$ & $\begin{array}{l}\text { Domina } \\
\text { nce }\end{array}$ & $\begin{array}{l}\text { MRR } \\
(\%)\end{array}$ \\
\cline { 2 - 5 } & FYM & IF & 212.0 & 36040 & 0 & 36040 & - & 553.6 \\
T1 & 0 & 0 & 353.0 & 60061 & 3675 & 56386 & - & - \\
T2 & 50 & 50 & 327.2 & 55624 & 3687.5 & 51936.5 & D & - \\
T3 & 25 & 75 & 375.4 & 63818 & 3915.5 & 59902.4 & - & 609.4 \\
T5 & 75 & 25 & 308.3 & 52411 & 4137.5 & 48273.5 & D & - \\
T6 & 100 & 0 & 279.5 & 47515 & 4600 & 42915 & D & - \\
\hline
\end{tabular}

Trt $=$ Treatment $;$ TVC = Total Variable Cost $;$ D = dominated $;$ MRR= Marginal Rate of Return; FYM= Farm Yard Manure;

IF=inorganic fertilizer (Urea); Qt=Quital; $\mathrm{ha}^{-1}=$ per hectare

The first rate of return was recorded between treatment 1 and treatment 4 with a change in net income of 20346 Birr and a change in total variable cost of 3675 Birr. Therefore the Marginal rate of return was $553.6 \%$ or 5.53 birr. This means that for every 3675 Birr investment of a farmer in using $9 \mathrm{t} / \mathrm{ha}$ of FYM and $65 \mathrm{~kg}$ of inorganic fertilizer (Urea), farmers could expect to recover the 3675 birr and Birr and obtain additional 23862.4 Birr and have an economic advantage over the use of other alternative combinations. So, this is important to farmers to improve their income.

\section{Perception of Farmers to Use FYM for Tomato production}

Despite the high number of livestock per household and the availability of cheap family labor that could be used for FYM collection and transportation the use of FYM for increased irrigated tomato productivity is not a common practice in the area. According to the respondents, FYM is used mostly for major rain fed crops such as Maize, obtain additional 20346 Birr. Similarly as goes from treatment 4 to treatment 3, Marginal Rate of Return (MRR) is $609.4 \%$ or 6.09 Birr which is relatively highest in this experiment. This means that for every 3915.5 Birr investment of a farmer in using 4.5t/ha of FYM and $97.7 \mathrm{~kg}$ of inorganic fertilizer (Urea), farmers could expect to recover the 3915.5 Sorghum and Finger millet. Even though livestock manure is highly respected by the farmers as a soil fertility improvement, the collection, storage and application method is not practiced properly and only used in the rain fed crops. The chi-square test indicated that there isa significant difference $(\mathrm{p}<0.01)$ among the three 'kebeles 'in the use of the FYM in irrigated tomato production. Relatively more farmers in M/ani were used FYM for tomato production (Table 4). Even though farm yard manure was easily accessed to the farmers about $43.1 \%$ of them were not used for tomato production because of different reasons (Table 5 
Table.4: Farmers experience in the use of FYM for irrigated tomato production

\begin{tabular}{|c|c|c|c|c|c|c|c|c|}
\hline \multirow[t]{2}{*}{ Question } & \multirow{2}{*}{$\begin{array}{l}\text { Respons } \\
\text { e }\end{array}$} & \multicolumn{3}{|c|}{ Kebele Name } & \multirow[t]{2}{*}{ Total } & \multirow[t]{2}{*}{ Percent } & \multirow[t]{2}{*}{$\mathbf{X}^{2}$} & \multirow[t]{2}{*}{ significance } \\
\hline & & Whdet & M/alem & M/ani & & & & \\
\hline \multirow{3}{*}{$\begin{array}{l}\text { Do you use FYM for } \\
\text { tomato production in } \\
\text { your irrigation site? }\end{array}$} & Yes & 15 & 16 & 10 & 41 & 56.9 & & \\
\hline & No & 22 & 4 & 5 & 31 & 43.1 & \multirow[b]{2}{*}{8.97} & \multirow[b]{2}{*}{$0.011 * *$} \\
\hline & Total & 37 & 20 & 15 & 72 & 100 & & \\
\hline
\end{tabular}

$X^{2}=$ Chi-square test $; * *=$ significant $p<0.01$

Table.5: Main reasons of farmers for do not use FYM in tomato production

\begin{tabular}{llll}
\hline S/N & Main reasons & Frequency & percentage \\
\hline & & & \\
1 & Lack of know how & 18 & 42.8 \\
2 & Labor shortage and far from the source & 13 & 31 \\
3 & Priority to use IF & 10 & 23.8 \\
4 & Disease and weed problems & 1 & 2.4 \\
\hline & Total & $\mathbf{4 2}$ & $\mathbf{1 0 0}$
\end{tabular}

As depicted in table 5from the farmers which do not use FYM for irrigated tomato production, $42.8 \%$ were because of the lack of know how whether FYM is important for tomato production or not, $31 \%$ of the farmers responded that due to labor shortage and far from the source, $23.8 \%$ of the respondents give priority to inorganic fertilizers as a nutrient sources and the remaining $2.4 \%$ answered as due to diseases and weed problems of the FYM.

Farmers' perception to use of Inorganic fertilizers in tomato production

The results depicted in (Table 6) showed that all most all of the respondent farmers

(94.4\%) in the study area were using inorganic fertilizer for tomato production. $5.6 \%$ of the respondent farmers were not used inorganic fertilizers because of different reasons. In terms of the economic feasibility of inorganic fertilizer for tomato production, $(48.61 \%)$ of respondents argued that use of inorganic fertilizer is better to gain better profit, whereas more than half $(51.39 \%)$ of the farmers respond that use of inorganic fertilizers is not economically feasible. From the $37(53.9 \%)$ respondent farmers who answered inorganic fertilizer is not economically feasible, $12.9 \%$ of them viewed because price of inorganic fertilizer is high, $83.88 \%$ of them respond because the current market the price of the vegetables (tomato) is below the initial price of the inputs used for production and the rest $3.2 \%$ of the respondent farmers answered that due to the burning effect of inorganic fertilizers especially after first harvest.

Table.6: Farmers experience and perception on Inorganic fertilizer for tomato production

\begin{tabular}{|c|c|c|c|c|c|c|}
\hline \multirow[t]{2}{*}{ Questions } & \multirow{2}{*}{$\begin{array}{l}\text { Respons } \\
\text { e }\end{array}$} & \multicolumn{3}{|c|}{ Kebele Name } & \multirow[t]{2}{*}{ Total } & \multirow[t]{2}{*}{$\%$} \\
\hline & & Whdet & M/alem & M/ani & & \\
\hline \multirow{3}{*}{$\begin{array}{l}\text { Do you use IF to increase your tomato } \\
\text { productivity? }\end{array}$} & Yes & 35 & 18 & 15 & 68 & 94.4 \\
\hline & No & 2 & 2 & 0 & 4 & 5.6 \\
\hline & Total & 37 & 20 & 15 & 72 & 100 \\
\hline Do you really believe that use of IF in & Yes & 18 & 5 & 14 & 37 & 51.39 \\
\hline
\end{tabular}




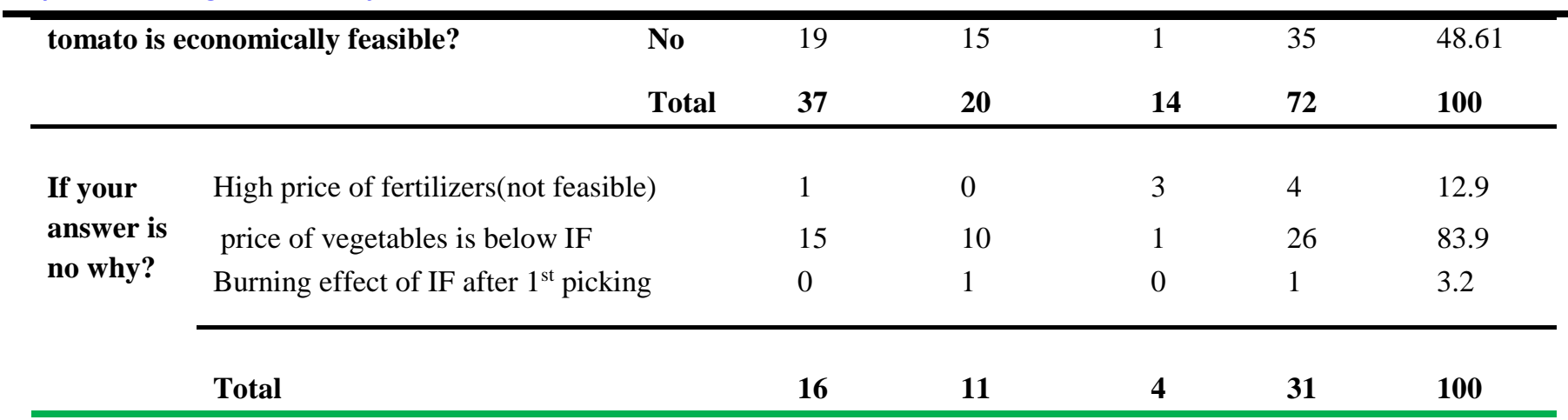

\section{Perception of Judicious Use of FYM with Inorganic} Fertilizers

Farmers' perception to integrated use of organic and inorganic fertilizer for tomato production showed in (Table 7).The result indicates that the sole use of FYM and inorganic fertilizers were practiced by an equal percentage (27.8\%) of respondents. Majorities (44.44\%) of the respondents were using the integration of organic (FYM) and inorganic (Urea) nutrient sources for better tomato productivity. The main reasons why farmers are interested to use the integration of both nutrient sources for tomato production is concentrated on three reasons. As depicted in
( Table 7), 65\% of the total respondent farmers in the study 'kebeles' used integrated nutrient management for tomato for the advantage of early and better performance of the crop, $18.8 \%$ of the respondents use for soil fertility improvement and the remaining $15.5 \%$ used integrated nutrient management for sustainable crop production. This agrees with the findings of Charreau (1991), who reported, higher and sustainable crop yields are achieved with the same amount of nutrients when supplied through combined use of organic and inorganic fertilizers than mineral fertilizer or organic alone.

Table.7: Farmers perception to integrated use of nutrients for tomato production

\begin{tabular}{|c|c|c|c|c|c|c|c|}
\hline \multirow{2}{*}{\multicolumn{3}{|c|}{ Questions }} & \multicolumn{3}{|c|}{ Kebele Name } & \multirow[t]{2}{*}{ Total } & \multirow[t]{2}{*}{$\%$} \\
\hline & & & Whdet & M/alem & M/ani & & \\
\hline \multirow{3}{*}{\multicolumn{2}{|c|}{$\begin{array}{l}\text { Which type of plant nutrient } \\
\text { sources is better for tomato } \\
\text { productivity }\end{array}$}} & FYM only & 8 & 11 & 1 & 20 & 27.8 \\
\hline & & IF only & 14 & 1 & 5 & 20 & 27.8 \\
\hline & & Integration of both & 15 & 8 & 9 & 32 & 44.4 \\
\hline & & Total & 37 & 20 & 15 & 72 & 100 \\
\hline \multirow{4}{*}{$\begin{array}{l}\text { If your } \\
\text { answer is } \\
\text { integration } \\
\text { of both } \\
\text { why? }\end{array}$} & \multicolumn{2}{|c|}{ Early and better performance of the crop } & 10 & 5 & 6 & 21 & 65.6 \\
\hline & \multicolumn{2}{|c|}{ Soil fertility improvement } & 3 & 2 & 1 & 6 & 18.8 \\
\hline & \multicolumn{2}{|c|}{ Sustainable crop production } & 2 & 1 & 2 & 5 & 15.6 \\
\hline & \multicolumn{2}{|l|}{ Total } & 15 & 8 & 9 & 32 & 100 \\
\hline
\end{tabular}

IV. CONCLUSION

Based on the current market price of inputs and outputs, the economic analysis indicates that all fertilized treatments (either integrated or lone) record higher net returns over the control treatment. From the present day experiment, treatments which received integration of FYM and inorganic fertilizers at the rate of $25 \% \mathrm{~N}$ from FYM with $75 \% \mathrm{~N}$ from inorganic sources resulted a maximum net of 
return,i.e, $15.4 \%$ more than the use of sole inorganic fertilizers and $39.6 \%$ more than the use of FYM only. Generally, in order to improve farmers' income decision cannot be taken regarding only the agronomic observations without knowing what rate of return is acceptable to the farmers rather; attention should be given to the net benefits because higher yield does not necessarily mean higher net benefit.

Based on the findings, regarding the social perceptions to the integrated use of organic and inorganic nutrient sources for irrigated tomato production, it can be concluded that, almost half of the respondents do not use FYM only for tomato production, because of lack of know-how, Priority to use inorganic fertilizers, labor shortage and disease and weed problems. Similarly, half of the respondent farmers perceive that, use of inorganic fertilizers is not economically feasible due to the high price of fertilizer, the low market price of tomato and burning effect of inorganic fertilizers especially after first picking. So farmers are interested on the integrated use of both nutrient sources for the advantage of early and better performance of tomato crops, soil fertility improvement and sustainable crop production.

To get better yield and higher economic benefit from irrigated tomato productions Every concerned stakeholder should give due attention to locally available nutrient resources (FYM) and the integrated use with Inorganic fertilizer for sustainable tomato production.

\section{CONFLICT OF INTEREST}

The author(s) have not declared any conflict of interests.

\section{AKNOWLEDGEMENTS}

This research was conducted in partial fulfillment of the M.Sc degree at Mekelle University by the first author. Funding was provided by the SIDA project.

\section{REFERENCES}

[1] Alam S.M.,TahirS.A.,Shah and AliS. (2004). Phosphorus management in wheat rice rotation through integrated use fertilizers, Beneficial effect on yield and profitability.Pak.J.Soil Sci.23:23-27.

[2] AstewelTakele, (2010). Analysis of rice profitability and marketing chain: The Case of FogeraWoreda, South Gondar Zone, Amhara National Regional State, Ethiopia MscThesis, HaramayaUniversity,Ethiopia.

[3] Bayu W., Rethman N.F.G., Hammes P.S., Alemu, G. (2006).Effect of farmyard manure and inorganic fertilizers on sorghum growth, yield and nitrogen use in semi-arid areas of Ethiopia. Journal of Plant Nutrition 29, 391-407.

[4] Chouichom S. and Yamao M. (2010).Comparing opinions and attitudes of organic andnon-organic farmers towards organic wheat farming system in north-eastern Thailand, Journal of Organic Systems, pp-25.

[5] Christopher M., and Stephen F. (1994). An economic analysis of ecological, agricultural Technologies among Peasant Farmers in Honduras. Ecological Economics 12 (1995):237-248. USA.

[6] CIMMYT (1988).From agronomic data to farmer recommendations: An e conomicstraining manual. Completely revised Edition. Mexico.

[7] CSA.(2007).Central Statistical Agency of Ethiopia.

[8] Duncan B., Eric C., Mark K. and Bruno H. (1990). Economic Analysis of On-Farm Trials: A review of approaches, and implications for research program design, department of agricultural economics, Staff Paper No. 90-78, Michigan State University, USA.

[9] Hailu Araya (2010). The effect of compost on soil fertility Enhancement and yield increment under smallholder farming, The case of Tahtai-Maichew district - Tigray region, Ethiopia, University of Hohenheim, Germany, PhD Thesis.

[10] Mekuria M. and Waddington S.R. (2002). Initiatives to encourage farmer adoption of soil fertility technologies for maize -based cropping systems in Southern Africa.

[11] MyARC (2010). Maitsebri Agricultural Research Center: Rice Production Techniques:Manual, Maitsebri, Tigray, Ethiopia.

[12] Place F., Christopher B., Barrett B., Freeman A., Bernard D. and Vanlauwe, D. ( 2030. Prospects for integrated soil fertility management using organic and inorganic inputs: Evidence from smallholder African agricultural systems. Food Policy 8(2003): 365-378

[13] TesfayBeshah (2003).Understanding farmers: Explaining soil and water conservation in Konso, Wolaita and Wollo, Ethiopia. Tropical Resourse Management Papers.

[14] Tolessa D., Friensen D.K. (2001). Effect of farmyard manure with mineral fertilizer on grain yield of maize at Bako, western Ethiopia.Seventh Eastern and Southern Africa Regional Maize Conference. 11th15th February. 335-337. Volume 2. New York.

[15] Van de Ban and Hawkins, A.W. (1998). Agricultural Extension (2nd ed.). Blackwell Science, Nethrlands. 